\title{
Wolff-Parkinson-White (WPW) Syndrome Catheter Ablation in Prince Sultan Cardiac Center
}

Ibrahim Yaseen M Osman*, Yahya Alhebaishi, Lamia Alshengeiti, Khalid Dagriri, Adil Asman, Salih Alghamd, Mohammed Mosaad, Ahmed Alfaqih

Saudi board in general cardiology MBBS University Og Gezira-Sudan, KSA.

*Corresponding Author: Ibrahim Yaseen M Osman, Saudi board in general cardiology MBBS University Og Gezira-Sudan, KSA.

Received date: May 28, 2021; Accepted date: July 02, 2021; Published date: July 09, 2021

Citation: Ibrahim Yaseen M Osman, Yahya Alhebaishi, Lamia Alshengeiti, Khalid Dagriri, Adil Asman, et all (2021) Wolff-Parkinson-White (WPW) Syndrome Catheter Ablation in Prince Sultan Cardiac Center. J. Clinical Cardiology and Cardiovascular Interventions. 4(14); DOI:10.31579/2641-0419/178

Copyrights: (c) 2021 Ibrahim Yaseen M Osman, This is an open-access article distributed under the terms of The Creative Commons Attribution License, which permits unrestricted use, distribution, and reproduction in any medium, provided the original author and source are credited

\begin{abstract}
Despite being one of the most common causes of supraventricular tachycardia in young adult, there are not many studies that highlight the demographics data as well as procedural characteristics of accessory pathway in Saudi Arabia.
\end{abstract}

Keywords: wolff-parkinson-white; supraventricular tachycardia

\section{Introduction}

Wolff-Parkinson-White (WPW) syndrome is an extra electrical accessory pathway between the heart's chambers without a rapid heart rate. Electrocardiogram of patients with WPW pattern demonstrates a short PR interval and prolonged QRS with a delta wave. Management of such condition is through an electrophysiological intervention called catheter ablation which may permanently correct the underlying heart problem. The aim of this study is to evaluate...

\section{Analysis Methods}

\section{Study Design}

All patients who were diagnosed with WPW in a single institution in Riyadh, Saudi Arabia from January 2009 to March 2020 were included in this retrospective study. Some of patients were attempted to be treated with catheter ablation but was not done due to Patients' data were obtained by the review of electronic medical records. Data collection included demographic data, type of atrioventricular accessory pathway (AP), location of AP, procedural data, type of ablation and type of tip catheter used.

\section{Indication and Patient Selection}

Catheter Ablation Procedure

Statistical Analysis
Continuous variables were reported as mean \pm standard deviation or median and $25^{\text {th }}$ to $75^{\text {th }}$ percentile. Categorical variables were presented as counts and percentages. Independent T-test were used to compare the difference between groups for normally distributed variables while MannWhitney U test for non-normally distributed variables and Pearson's chisquare test or fisher's exact test for categorical variables as appropriate. Continuous variable distribution was evaluated by Kolmogorov-Smirnov test. A two-sided P-value $<0.05$ was considered statistically significant. All analyses were performed using IBM-SPSS version 25 (IBM corp., Armonk, New York).

Two hundred seventeen patients with AP were enrolled from January 2009 till March 2020. Catheter ablation was performed in 207 (95.4\%) patients. Successful ablation was achieved in 197 (95.2\%) of patients. Median procedure time for all catheter ablation procedure was 110 minutes. Cryoablation [174 (125.13.8) minutes] was significantly longer than radio frequency ablation $[110(76,155$ minutes $)](\mathrm{p}=0.018)$.

\section{Results}

Two hundred seventeen patients with WPW were enrolled in the registry from January 2009 to March 2020. Catheter ablation was performed in $207(95.4 \%)$ patients. Success ablation was achieved in $197(95.2 \%)$ of patients. Patients' baseline characteristics and accessory pathway location were summarized in Table 1. 


\begin{tabular}{|l|l|}
\hline Characteristics & Value \\
\hline Age & $28.9 \pm 14.3$ \\
\hline Children (<18 y) & $47(21.7)$ \\
\hline Young adults (18-35 y) & $108(49.8)$ \\
\hline Middle adults (36-55 y) & $51(23.5)$ \\
\hline Older adults (>55) & $11(5.1)$ \\
\hline Male & $136(62.7)$ \\
\hline Female & $81(37.3)$ \\
\hline Type of accessory pathway & \\
\hline Manifest pre-excitation & $184(84.8)$ \\
\hline Concealed & $33(15.2)$ \\
\hline Accessory pathway & \\
\hline Left & $106(48.8)$ \\
\hline Right & $111(51.2)$ \\
\hline Location of accessory pathway & \\
\hline Left anterior/ anterolateral & $32(14.7)$ \\
\hline Left lateral & $34(15.7)$ \\
\hline Left posterior/ posterolateral & $27(12.4)$ \\
\hline Left septal/ posteroseptal & $13(6)$ \\
\hline Right lateral / anterolateral / posterolateral & $13(6)$ \\
\hline Right posterior & $2(0.9)$ \\
\hline Right anterior & $5(2.3)$ \\
\hline $\begin{array}{l}\text { Right septal / mid septal / anteroseptal } \\
\text { posteroseptal }\end{array}$ & $72(33.2)$ \\
\hline Parahisian & $19(8.8)$ \\
\hline
\end{tabular}

Table 1: Baseline characteristics and location of accessory pathway of patients with WPW.

\begin{tabular}{|l|l|}
\hline Characteristics & Value \\
\hline Successful ablation $(\mathrm{n}=207)$ & $197(95.2)$ \\
\hline 3D Mapping & $41(18.9)$ \\
\hline Transeptal & $110(50.7)$ \\
\hline Radiofrequency $(\mathrm{n}=207)$ & $195(89.9)$ \\
\hline Cryoablation $(\mathrm{n}=207)$ & $12(5.5)$ \\
\hline Irrigated $(\mathrm{n}=207)$ & $15(6.9)$ \\
\hline Non-irrigated $(\mathrm{n}=207)$ & $192(88.5)$ \\
\hline Procedure duration, minutes & $110(75,160)$ \\
\hline
\end{tabular}

Table 2: Procedural data

\begin{tabular}{|c|c|c|c|}
\hline Variable & $\begin{array}{c}\text { Successful Ablation } \\
(\mathrm{n}=197)\end{array}$ & $\begin{array}{c}\text { Failed Ablation } \\
(n=10)\end{array}$ & p-value \\
\hline Age & $28.4 \pm 13.6$ & $32 \pm 18.1$ & 0.430 \\
\hline Children $(<18 \mathrm{y})$ & $42(21.3)$ & $3(30)$ & \multirow{4}{*}{0.490} \\
\hline Young adults $(18-35 \mathrm{y})$ & $102(51.8)$ & $3(30)$ & \\
\hline Middle adults (36-55 y) & $46(23.4)$ & $3(30)$ & \\
\hline Older adults $(>55)$ & $7(3.6)$ & $1(10)$ & \\
\hline Male & $125(63.5)$ & $6(60)$ & \multirow{2}{*}{1.000} \\
\hline Female & $72(36.5)$ & $4(40)$ & \\
\hline Manifest & $170(86.3)$ & $7(70)$ & \multirow{2}{*}{0.153} \\
\hline Concealed & $27(13.7)$ & $3(30)$ & \\
\hline \multicolumn{4}{|l|}{ Location of AP } \\
\hline Left anterior/ anterolateral & $32(16.2)$ & 0 & \multirow{9}{*}{$<0.001$} \\
\hline Left lateral & $33(16.8)$ & 0 & \\
\hline Left posterior/ posterolateral & $27(13.7)$ & 0 & \\
\hline Left septal/ posteroseptal & $13(6.6)$ & 0 & \\
\hline Right lateral / anterolateral / posterolateral & $12(6.1)$ & $1(10)$ & \\
\hline Right posterior & $2(1.0)$ & 0 & \\
\hline Right anterior & $4(2.0)$ & 0 & \\
\hline $\begin{array}{l}\text { Right septal / mid septal / anteroseptal } \\
\text { posteroseptal }\end{array}$ & $65(33)$ & $2(20)$ & \\
\hline Parahisian & $9(4.6)$ & $7(70)$ & \\
\hline
\end{tabular}




\begin{tabular}{|l|c|c|c|}
\hline 3D Mapping & $37(18.8)$ & $2(20)$ & 0.923 \\
\hline Transeptal & $108(54.8)$ & $2(20)$ & 0.031 \\
\hline Radiofrequency & $188(95.4)$ & $7(70)$ & $<0.001$ \\
\hline Cryoablation & $9(4.6)$ & $3(30)$ & 0.004 \\
\hline Irrigated & $12(6.1)$ & $3(30)$ & 0.004 \\
\hline Non-irrigated & $185(93.9)$ & $7(70)$ & \multirow{2}{*}{0} \\
\hline
\end{tabular}

Table-3: Characteristics of patients by outcome of catheter ablation

\begin{tabular}{|c|c|c|c|}
\hline Variable & $\begin{array}{c}\text { Male } \\
(n=136)\end{array}$ & $\begin{array}{c}\begin{array}{c}\text { Female } \\
(n=81)\end{array} \\
\end{array}$ & p-value \\
\hline Age & $28.9 \pm 14.1$ & $28.8 \pm 14.8$ & 0.940 \\
\hline Children $(<18 \mathrm{y})$ & $25(18.4)$ & $22(27.2)$ & \multirow{4}{*}{0.294} \\
\hline Young adults $(18-35 \mathrm{y})$ & $74(54.4)$ & $34(42)$ & \\
\hline Middle adults (36-55 y) & $30(22.1)$ & $21(25.9)$ & \\
\hline Older adults $(>55)$ & $7(5.1)$ & $4(4.9)$ & \\
\hline Manifest & $115(84.9)$ & $69(85.2)$ & \multirow{2}{*}{0.901} \\
\hline Concealed & $21(15.4)$ & $12(14.8)$ & \\
\hline \multicolumn{4}{|l|}{ Accessory pathway } \\
\hline Left & $75(55.1)$ & $31(38.3)$ & \multirow{2}{*}{0.016} \\
\hline Right & $61(44.9)$ & $50(61.7)$ & \\
\hline \multicolumn{4}{|l|}{ Location of AP } \\
\hline Left anterior/ anterolateral & $25(18.4)$ & $7(8.6)$ & \multirow{9}{*}{0.022} \\
\hline Left lateral & $25(18.4)$ & $9(11.1)$ & \\
\hline Left posterior/ posterolateral & $19(14)$ & $8(9.9)$ & \\
\hline Left septal/ posteroseptal & $6(4.4)$ & $7(8.6)$ & \\
\hline Right lateral / anterolateral / posterolateral & $4(2.9)$ & $9(11.1)$ & \\
\hline Right posterior & $2(1.5)$ & 0 & \\
\hline Right anterior & $4(2.9)$ & $1(1.2)$ & \\
\hline $\begin{array}{l}\text { Right septal / mid septal / anteroseptal } \\
\text { posteroseptal }\end{array}$ & $28(27.9)$ & $34(42)$ & \\
\hline Parahisian & $13(9.6)$ & $6(9.4)$ & \\
\hline 3D Mapping & $28(20.6)$ & $13(16$ & 0.409 \\
\hline Transeptal & $76(55.9)$ & $34(42)$ & 0.047 \\
\hline Successful ablation & $125(95.4)$ & $72(94.7)$ & 0.825 \\
\hline Radiofrequency & $123(93.9)$ & $72(94.7)$ & \multirow{2}{*}{0.802} \\
\hline Cryoablation & $8(6.1)$ & $4(5.3)$ & \\
\hline Irrigated & $9(6.9)$ & $6(7.9)$ & \multirow{2}{*}{0.784} \\
\hline Non-irrigated & $122(93.1)$ & $70(92.1)$ & \\
\hline Procedure time & $112.5(71.3,155)$ & $109(85,168.5)$ & 0.589 \\
\hline
\end{tabular}

Table 4: Patients' baseline and procedural characteristics by gender

Median procedure time for all catheter ablation procedure was $110(75,160)$ minutes. Cryoablation [174 (125.193.8) minutes] was significantly longer than Radiofrequency ablation $[110(76,155$ minutes $)](\mathrm{p}=0.018)$ as shown in Figure 1.

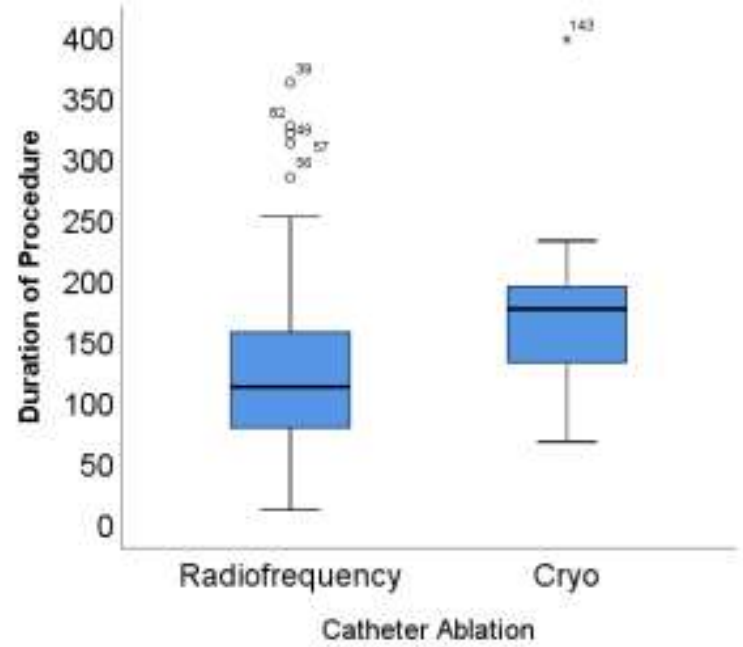




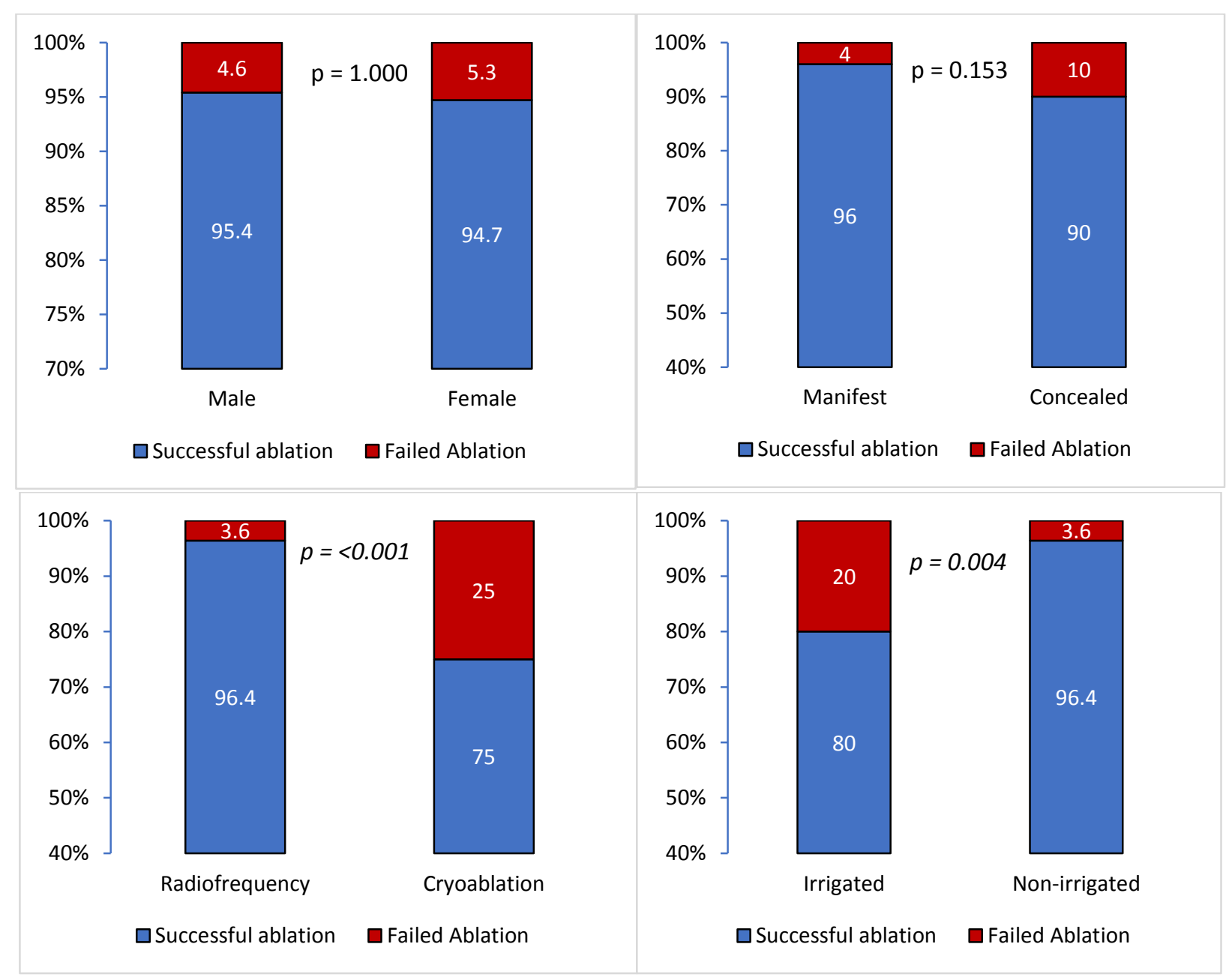

Figure 2: Percentage of patients' ablation outcomes according to (A) gender (B) type of accessory pathway $(C)$ catheter ablation procedure (D) catheter tip

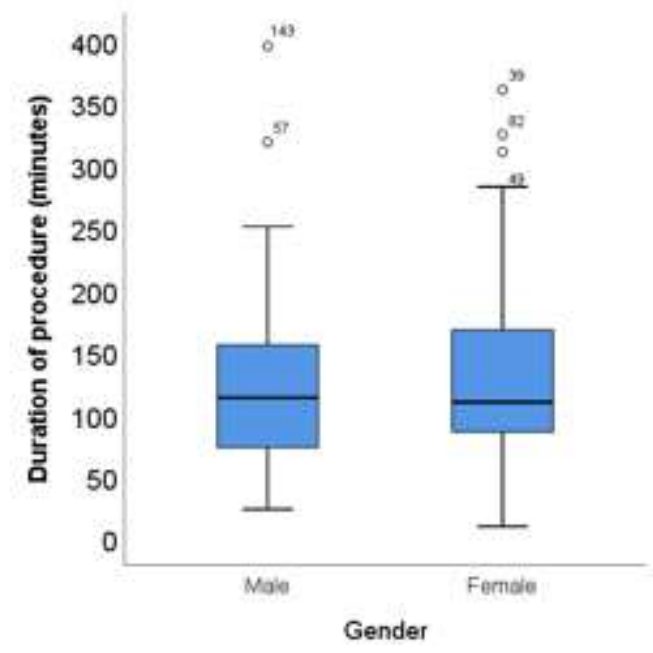




\section{Conclusion}

The patients with the diagnosis of WPW who had received radiofrequency ablation specially irrigated type were associated with a higher success rate compared with those received cryoablation.

The highest percentage of accessory pathway is allocated in Right septal region. High success rate in adults than pediatric patients. Radiofrequency ablation may account for higher success rate in comparison with cryoablation in different situations even procedure duration is less. Therefore, the radiofrequency ablation strategies should be implemented.

\section{Discussion}

A large proportion of WPW syndrome patients are asymptomatic so, WPW syndrome is considered as benign disease. [1] In all groups age and male gender were risk factors for recurrence in patients with PSVT. [2]

After proven that catheter ablation of accessory pathway mostly eliminate the risk of sudden cardiac death and restore normal ventricular function in patients with dys-synchrony and impaired left ventricular function prior to ablation. So, considered catheter ablation is the first line in treating of symptomatic WPW syndrome patients $[1,8,9]$

However Catheter ablation become a standard therapy in patients with symptomatic Wolff-Parkinson-White (WPW) syndrome, It is still questionable in asymptomatic WPW patient should receive ablation or not. In asymptomatic patients with high-risk features international guidelines suggest that catheter ablation of accessory pathway is reasonable including inducible atrioventricular reentrant tachycardia (AVRT), inducible atrial fibrillation (AF) with preexcitation, and the presence of multiple accessory pathways. [6,7] symptomatic and asymptomatic patients were included. All age groups were included, and all patients were collected from a local, nonreferred population. [4,5]

With the great technology development and electrophysiology practice in the last 20 years, there is quantum leap by inventing RF and cryoenergy to ablate near the compact AV node using automated computer system and development of 3-dimentional mapping that map and visualize enhanced substrate which improve Electrophysiologists capability. $[10,11]$

The main ability of these tools is to increase success rates with ablation, also maximum improvement achieved by decreasing the number of lesions needed for a successful ablation. [23]

In our study, we found that automated signal analysis tools provides satisfying diagnosis accuracy for distinguishing the site of a successful ablation with WPW. These advanced tools available for ablation of WPW may expand and provide an additional equipments and instruments in the EP laboratory. [12]

Patients who underwent cryoablation or who were atrially paced were excluded and all left-sided pathways were approached from a transseptal approach. In this analysis, we included two distinct EP laboratories and numerous different ablation catheters, patients who underwent cryoablation, patients who were atrially paced during ablation, patients with congenital heart disease, and patients who underwent ablation of a left-sided pathway via a retrograde approach [23]

Although good success rates for WPW ablation there is always trend to improve our technical abilities and success rates and minimizing the number of lesions during ablation. Many causes for unsuccessful ablation were demonstrated. patient factors like location of the accessory pathway (near AV node or epicardial location) or operator factors like experience and technical ability, inadequate temperature or power delivery during ablation attempts, poor tissue contact, and or inappropriate analysis of the intracardiac signals. [13,14]

In addition to minimizing the number of unnecessary ablation lesion, one of the benefits is related to the strong predictive ability in the right lateral region of the tricuspid annulus. Demonstration of ablation success rates are low in the right lateral region as low as $85 \%$ and a high recurrence rate of up to $16 \%$. $[3,13,15,16]$

\section{References:}

1. Pappone C, Vicedomini G, Manguso F, Saviano M, Baldi M, Pappone A et al. Wolff-Parkinson-White syndrome in the era of catheter ablation: insights from a registry study of 2169 patients. Circulation 2014;130:811-819

2. Trend and Risk Factors of Recurrence and Complications After Arrhythmias Radiofrequency Catheter Ablation: A NationWide Observational Study in Taiwan.

3. Van Hare GF, Javitz H, Carmelli D, Saul JP, Tanel RE, et al. (2004) Prospective assessment after pediatric cardiac ablation: recurrence at 1 year after initially successful ablation of supraventricular tachycardia. Heart Rhythm 1: 188-196.

4. Al-Khatib SM, Arshad A, Balk EM, Das SR, Hsu JC, Joglar JA et al. Risk stratification for arrhythmic events in patients with asymptomatic pre-excitation: a systematic review for the 2015 ACC/AHA/HRS guideline for the management of adult patients with supraventricular tachycardia: a report of the American College of Cardiology/American Heart Association task force on clinical practice guidelines and the Heart Hhythm Society. J Am Coll Cardiol 2016;67:1624-1638.

5. Katritsis DG, Boriani G, Garcia-Cosio F, Jais P, Josephson ME, Hindricks $G$ et al. European Heart Rhythm Association (EHRA) consensus document on the management of supraventricular arrhythmias, endorsed by Heart Rhythm Society (HRS), Asia-Pacific Heart Rhythm Society (APHRS), and Sociedad Latinoamericana de Estimulacioen Cardiaca y Electrofisiologia (SOLAECE). Europace 2017;19:465-511.

6. Papagiannis JAD, Alexopoulos C, Kirvassilis G (2011) Radiofrequency ablation of accessory pathways in children and congenital heart disease patients: impact of a nonfluoroscopic navigation system. Pacing Clin Electrophysiol 34: 288-296.

7. Shurrab MDBL, Briceno DF, Kaoutskaia A, Haj-Yahia S, Newman D, Lashevsky I, Nakagawa H, Crystal E,. (2015. September) Impact of Contact Force Technology on Atrial Fibrillation Ablation: A Meta-Analysis. J Am Heart Assoc 4: e002476

8. Tomaske M, Janousek J, Razek V, Gebauer RA, Tomek V, Hindricks $\mathrm{G}$ et al. Adverse effects of Wolff-Parkinson-White syndrome with right septal or posteroseptal accessory pathways on cardiac function. Europace 2008;10:181-189.

9. Kwon BS, Bae EJ, Kim GB, Noh CI, Choi JY, Yun YS. Septal dyskinesia and global left ventricular dysfunction in pediatric Wolff-Parkinson-White syndrome with septal accessory pathway. J Cardiovasc Electrophysiol 2010;21:290-295.

10. Ceresnak SR, Dubin AM, Kim JJ, Valdes SO, Fishberger SB, et al. (2015) Success rates in pediatric WPW ablation are improved with 3-dimensional mapping systems compared with fluoroscopy alone: a multicenter study. Journal of Cardiovascular Electrophysiology 26: 412-416.

11. Friedman PL, Dubuc M, Green MS, Jackman WM, Keane DT, et al. (2004) Catheter cryoablation of supraventricular tachycardia: results of the multicenter prospective "frosty" trial. Heart Rhythm 1: 129-138. 
12. Validation of a novel automated signal analysis tool for ablation of Wolff-Parkinson-White Syndrome. PLoS One. 2019; 14(6): $\mathrm{e} 0217282$.

13. Morady F, Strickberger A, Man KC, Daoud E, Niebauer M, et al. (1996) Reasons for prolonged or failed attempts at radiofrequency catheter ablation of accessory pathways. J Am Coll Cardiol 27: 683-689.

14. Sacher F, Wright M, Tedrow UB, O'Neill MD, Jais P, et al. (2010) Wolff-Parkinson-White ablation after a prior failure: a 7-year multicentre experience. Europace 12: 835-841.
15. Kugler JD, Danford DA, Houston K, Felix G (1997) Radiofrequency catheter ablation for paroxysmal supraventricular tachycardia in children and adolescents without structural heart disease. Pediatric EP Society, Radiofrequency Catheter Ablation Registry. Am J Cardiol 80: $1438-1443$.

16. Kugler JD, Danford DA, Houston KA, Felix G (2002) Pediatric radiofrequency catheter ablation registry success, fluoroscopy time, and complication rate for supraventricular tachycardia: comparison of early and recent eras. J Cardiovasc Electrophysiol 13: 336-341. his work is licensed under Creative

Commons Attribution 4.0 License

To Submit Your Article Click Here: Submit Manuscript

DOI: $10.31579 / 2641-0419 / 178$
Ready to submit your research? Choose Auctores and benefit from:

* fast, convenient online submission

* rigorous peer review by experienced research in your field

* rapid publication on acceptance

* authors retain copyrights

* unique DOI for all articles

* immediate, unrestricted online access

At Auctores, research is always in progress.

Learn more www.auctoresonline.org/journals/clinical-cardiology-andcardiovascular-interventions 